\title{
Betahistine dihydrochloride quantitative determination in dosage forms by the reaction with sodium 1,2-napthoquinone- 4-sulphonate
}

\author{
A. O. Donchenko, S. 0. Vasyuk
}

Zaporizhzhia State Medical University, Ukraine

Key words:

betahistine

dihydrochloride, sodium

1,2-napthoquinone-

4-sulphonate,

spectrophotometry,

validation studies.

\section{Zaporozhye}

medical journa

2018; 20 (2), 248-252

DOI:

10.14739/2310-1210

2018.2.125283

E-mail:

donchenk0130791@

gmail.com
Objectives. Spectrophotometric method is one of the most convenient methods in pharmaceutical analysis, as it is sensitive, precise and cost effective. Therefore, the aim of the present work was the development of simple and available method for the quantitative determination of betahistine dihydrochloride in dosage forms.

Materials and methods. Sodium 1,2-napthoquinone-4-sulphonate was assessed as chemical reagent for the quantitative determination of betahistine dihydrochloride by visible spectrophotometric method.

Results. Different variables affecting the reactions between sodium 1,2-napthoquinone-4-sulphonate and the drug were carefully studied and optimized. It was established that betahistine dihydrochloride reacts with sodium 1,2-napthoquinone-4-sulphonate in alkaline medium with the colored reaction product formation with absorption maximum at $485 \mathrm{~nm}$. The proposed method was subjected to validation tests. The method was validated for the parameters like linearity, precision, accuracy, robustness and scope of application. Beer's law was obeyed over the concentration range of $2.40-4.00 \mathrm{mg} / 100 \mathrm{ml}$. Parameters of linear dependence were calculated with the help of regression analysis by means of least squares. Coefficients of stoichiometric relationship were also determined by means of molar ratios and continuous changes. The proposed procedure meets the requirements of State Pharmacopoeia of Ukraine that are made for dosage forms.

Conclusion. On the basis of the carried out investigations of betahistine dihydrochloride quantitative determination, spectrophotometric procedure has been developed and validated. This procedure is successfully applied for dosage forms analysis. Investigation results show that the procedure is highly sensitive, precise, simple in performance and relevant to be applied at the quality control laboratories for dosage forms.
Кнючові слова:

бетагістину АигіАрохмориА натрієва сіль 1,2-нафтохінон4-сульфокислоти, спектрофотометрія, валідація.

Запорізький медичний журнак. - 2018. T. 20, № 2(107). C. 248-252

\section{Кікькісне визначення бетагістину дигідрохлориду в лікарських формах за реакцією з натрієвою сімю 1,2-нафтохінон-4-сульфокислоти}

\section{А. О. Аонченко, С. О. Васюк}

Спектрофотометричний метод - один із найбільш зручних методів у фармацевтичному аналізі, оскільки він чутливий, точний та економічний.

Мета роботи - розробка простої та доступної методики кількісного визначення бетагістину дигідрохлориду в лікарських формах.

Матеріали та методи. Натрієву сіль 1,2-нафттохінон-4-сульфоокислоти оцінювали як хімічний реагент для кількісного спектрофотометричного визначення бетагістину дигідрохлориду.

Результати. Різноманітні чинники, що впливають на взаємодію між натрієвою сіллю 1,2-нафртохінон-4-сульфокислоти та лікарською речовиною, ретельно вивчені, оптимізовані. Встановили, що бетагістину дигідрохлорид реагує з натрієвою сіллю 1,2-нафртохінон-4-сульфокислоти в лужному середовищі з утворенням забарвленого продукту реакції 3 максимумом абсорбції при 485 нм. Виконали валідацію розробленої методики. Перевірили основні валідаційні характеристики: лінійність, прецизійність, правильність, робастність і діапазон застосування. Підпорядкування закону Бера спостерігають у межах концентрації 2,40-4,00 мг/100 мл. Параметри лінійної залежності розрахували за допомогою регресійного аналізу методом найменших квадратів. Визначили коефіцієнти стехіометричних співвідношень методами молярних співвідношень і неперервних змін. Запропонована методика відповідає вимогам ДФУ, що ставлять до методик кількісного аналізу лікарських речовин.

Висновки. На підставі досліджень розроблено та валідовано спектрофотометричну методику кількісного визначення бетагістину дигідрохлориду, котру успішно застосували для аналізу лікарських фрорм. Результати дослідження свідчать, що методика $є$ високочутливою, точною, простою у виконанні та придатною для використання в лабораторіях контролю якості лікарських речовин.
Кмючевые слова: бетагистина АИгиАрОхлориА, натриевая соль 1,2-нафтохинон4-сульфокислоты, спектрофотометрия, валиАация.

\section{Количественное определение бетагистина дигидрохлорида в лекарственных формах по реакции с натриевой солью 1,2-нафтохинон-4-сульфокислоты}

\author{
А. А. Аонченко, С. А. Васюк
}

Спектрофотометрический метод является одним из самых удобных методов в фрармацевтическом анализе, поскольку он чувствительный, точный и экономичный.

Цель работы - разработка простой и доступной методики количественного определения бетагистина дигидрохлорида в лекарственных формах. 
Материалы и методы. Натриевую соль 1,2-нафтохинон-4-сульфокислоты оценивали как химический реагент для количественного спектрофотометрического определения бетагистина дигидрохлорида.

Результаты. Различные факторы, влияющие на взаимодействие между натриевой солью 1,2-нафтохинон-4-сульфокислоты и лекарственным веществом, тщательно изучены и оптимизированы. Установлено, что бетагистина дигидрохлорид реагирует с натриевой солью 1,2-нафтохинон-4-сульфокислоты в щелочной среде с образованием окрашенного продукта реакции с максимумом абсорбции при 485 нм. Проведена валидация разработанной методики. Проверены основные валидационные характеристики: линейность, прецизионность, правильность, робастность и диапазон применения. Подчинение закону Бера наблюдается в пределах концентрации 2,40-4,00 мг/100 мл. Параметры линейной зависимости рассчитали с помощью регрессионного анализа методом наименьших квадратов. Также определены коэффициенты стехиометрических соотношений методами молярных соотношений и непрерывных изменений. Предложенная методика соответствует требованиям ГФУ, которые предъявляют к методикам количественного анализа лекарственных веществ.

Выводы. На основе проведенных исследований разработана и валидирована спектрофотометрическая методика количественного определения бетагистина дигидрохлорида, которая успешно применена для анализа лекарственных форм. Результаты исследования свидетельствуют, что методика является высокочувствительной, точной, простой в исполнении и пригодной для использования в лабораториях контроля качества лекарственных веществ.

\section{Introduction}

Betahistine dihydrochloride (N-methyl-2-(2-pyridyl) ethylamine dihydrochloride) is a structural analogue of histamine by its pharmacological properties. The drug has mild agonistic action at $\mathrm{H}_{1}$-receptors and significant antagonistic in cerebrum and inner ear vessels as well as normalizes neurotransmission in cerebral and vestibular nuclei [1]. Betahistine dihydrochloride drugs are widely used in clinical practice for treatment of Meniere's syndrome and other vestibular disorders that are accompanied with faintness,

Betahistine dihydrochloride quantitative determination procedures with application of various physical and chemical methods such as potentiometric titration [3], HPLC [4], colorimetry [5] are described. But spectrophotometry is the most widely used for the assay of the drug $[6,7]$.

Spectrophotometric method is one of the most convenient methods in pharmaceutical analysis, as it is sensitive, precise, cost effective and available to quality control laboratories. Search of highly sensitive and low cost colored reagents is one of the problems of this method. Sodium 1,2-napthoquinone-4-sulphonate (NQS) meets these requirements.

For this purpose the development of highly sensitive, accurate and simple procedure of betahistine dihydrochloride quantitative determination in substance and dosage forms based on reaction with sodium 1,2-napthoquinone-4-sulphonate and validation of the worked out procedure was the objective of the work.

\section{Materials and methods}

The following dosage forms were used for investigation:

- tablets "Vestinorm", $24 \mathrm{mg}$ of betahistine dihydrochloride, "Farmak" PJSC, Ukraine, series No 551215;

- tablets "Maxhistin", $16 \mathrm{mg}$ of betahistine dihydrochloride, "FARMEKS GROUP" LLC, Ukraine, series No 3291116;

- tablets "Betahis", $16 \mathrm{mg}$ of betahistine dihydrochloride, "Farma Start", Ukraine, series No 540416.

Sodium 1,2-napthoquinone-4-sulphonate of "chemically pure" qualification, $\mathrm{NaOH}$ of "reagent grade" qualification one - at histamine $\mathrm{H}_{3}$-receptors in central and autonomous nervous system. It promotes blood circulation increase sonitus and earache, decrement in hearing acuity [2]. solvent. Betahistine dihydrochloride working standard (WS) was used as a standard.

Analytical equipment: Specord 200 spectrophotometer, ABT-120-5DM electrobalance, A class measuring glassware.

General procedure of betahistine dihydrochloride

$1,00 \mathrm{ml}$ of betahistine dihydrochloride standard solution $0.08 \%$ was placed into a measuring flask for $25 \mathrm{ml}$. Add $1 \mathrm{ml}$ of $0.5 \% \mathrm{NQS}$ and $1 \mathrm{ml}$ of $0.05 \mathrm{M} \mathrm{NaOH}$ and mix. Reaction mixture was allowed for $15 \mathrm{~min}$ at room temperature and brought up with distilled water to the mark. Absorption was measured at $485 \mathrm{~nm}$ against compensation solution blank that didn't contain investigated substance.

Procedure of betahistine dihydrochloride quantitative determination in tablets

Accurate quantity of tablet weight $(300 \mathrm{mg})$ was transferred to $25 \mathrm{ml}$ measuring flask and brought up to the mark with the distilled water. Received solution was mixed and filtered. First portions of filtrate were discarded. The aliquots of the received solution were analyzed according to the proposed procedure. and distilled water were used as chemical reagents and a quantitative determination
Запорожский медицинский журнал. - 2018. T. 20, № 2(107). C. 248-252

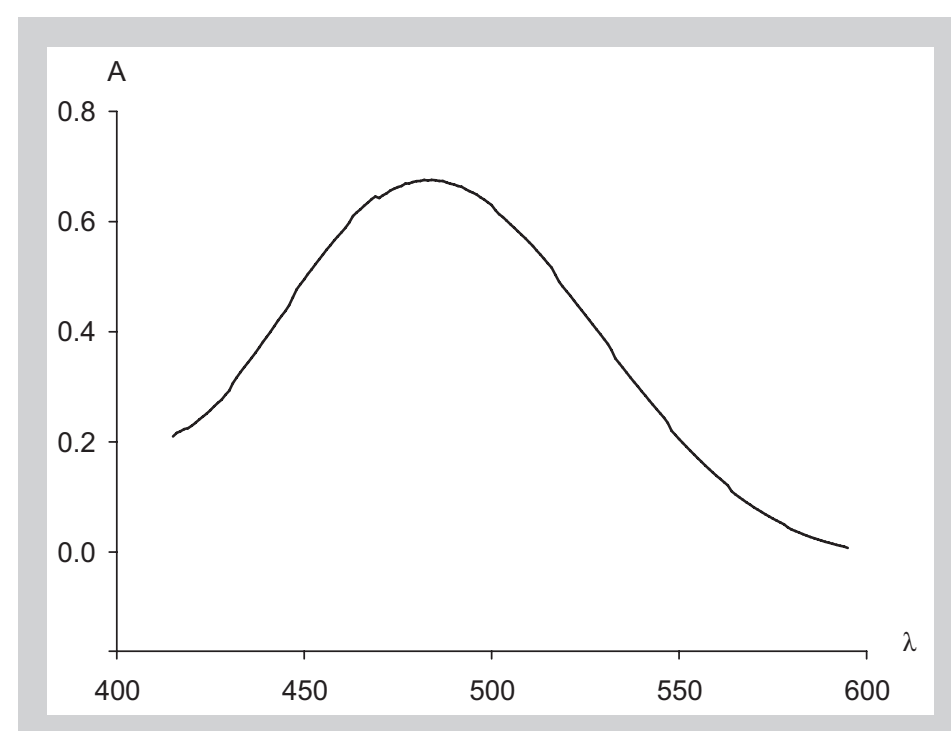

Fig. 1. Absorption spectrum of reaction product of betahistine dihydrochloride with sodium 1,2-napthoquinone-4-sulphonate. 

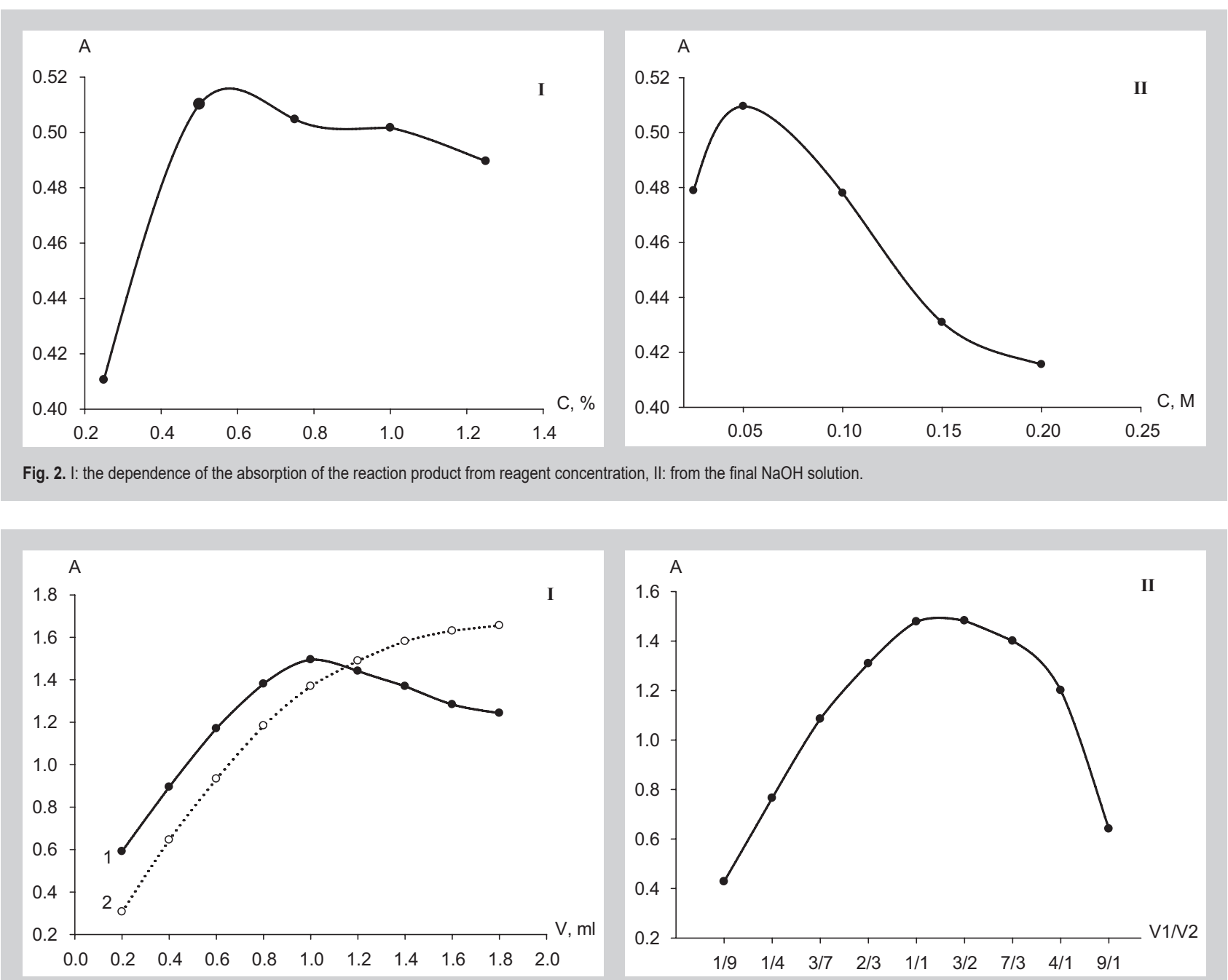

Fig. 3. Curves of betahistine dihydrochloride saturation at constant reagent concentration (1) and reagent at constant betahistine dihydrochloride concentration (2); II: diagram of dependence of the absorption from the isomolar solution composition (V1: $0.02 \mathrm{M}$ solution of sodium 1,2-napthoquinone-4-sulphonate, V2 - $0.02 \mathrm{M}$ solution of betahistine dihydrochloride).

\section{Results and discussion}

Highly sensitive, precise and simple betahistine dihydrochloride quantitative determination by visible spectrophotometry was developed and validated. The procedure is based on interaction of the dosage form with sodium 1,2-napthoquinone-4-sulphonate. In alkaline medium, the colored reaction product with absorption maximum at $485 \mathrm{~nm}$ was obtained (Fig. 1).

Optimum conditions to carry out the reaction between betahistine dihydrochloride and sodium 1,2-napthoquinone-4-sulphonate has been established while developing this procedure. We established the influence of reagent concentration at the reaction path. Necessary quantity of reagent was determined experimentally by reaction product maximum yield, i.e. by maximum value of absorbance. Absorption maximum was at $0.5 \%$ concentration of 1,2-napthoquinone-4-sulphonate (Fig. 2). That's why further investigation was carried out at $0.5 \%$ reagent solution.

It was experimentally proved that alkaline medium creation was obligatory for successful reaction path between betahistine dihydrochloride and sodium 1,2-napthoquinone-4-sulphonate. The dependence of absorption from the $\mathrm{NaOH}$ solution concentration is given on Fig. 2. $0.05 \mathrm{M}$ solution of $\mathrm{NaOH}$ was chosen as the optimum one.
Thereafter, the influence of time at the reaction product formation was studied. At room temperature the intensity of the investigated solution coloration increased in time, and absorption maximum was observed in $15 \mathrm{~min}$.

Coefficients of stoichiometric relationship were also determined by means of molar ratios and continuous changes. Stoichiometric relationships of reacting species "sodium 1,2-napthoquinone-4-sulphonate - betahistine dihydrochloride" were uniquely agree with each other and form 1:1 (Fig. 3).

The border of determination at optimum conditions was $0.24 \mu \mathrm{g} / \mathrm{ml}$, that showed the high sensitivity of the reaction.

Thereafter, the validation of the developed procedure was carried out according to the requirements of State Pharmacopoeia of Ukraine by means of standard [8,9]. Principal validation features, namely, linearity, precision, accuracy, robustness and scope of application were established.

Linearity

Linearity was determined in the range of concentration, in which submission to the Beer's law was observed, namely $2.40-4.00 \mathrm{mg} / 100 \mathrm{ml}$. The calibration graph of the absorption from betahistine dihydrochloride concentration was plotted according to the obtained data. It is given in Fig. 4. 
Parameters of linear dependence were calculated using the regression analysis by means of least squares. Received values are given in the Table 1.

Calculated numbers show that all requirements of State Pharmacopoeia of Ukraine concerning linear dependence parameters are met. Procedure scope of application is $70-130 \%$.

\section{Precision}

Precision was determined at level of coincidence. 9 samples, the concentrations of which were uniformly distributed in the investigated procedure range, were analysed. The comparison solution absorption was also measured. According to the State Pharmacopoeia of Ukraine requirements to precision, the procedure is accurate at level of coincidence, if unilateral confidence interval $(\Delta x)$ doesn't exceed the maximum allowable analysis uncertainty $(\Delta \mathrm{As} \%)$. The data of the table 2 show the accuracy of the developed procedure.

\section{Accuracy}

To establish the accuracy of the developed procedure, the standard addition method was used. Deferent amounts of betahistine dihydrochloride standard solution were added to three equal dosage forms samples and analysis was made three times. The results of determination were accurate, as significant systematic imprecision was absent, i.e. the real value was in the established confidence interval (Table 3).

\section{Robustness}

Robustness estimation was carried out at the stage of procedure development. Investigation of stability of analytical solutions in time was carried out for estimation of procedure robustness. Sample solution and comparison solution were stable within at least $30 \mathrm{~min}$.

\section{Conclusion}

On the basis of the carried out investigations of betahistine dihydrochloride quantitative determination, spectrophotometric procedure has been developed. This procedure is successfully applied for dosage forms analysis. Investigation results show that the procedure is highly sensitive, precise, simple and relevant to be applied at the quality control laboratories for dosage forms.

\section{References}

[1] Mashkovskij, M. D. (2012). Lekarstvennye sredstva [Drugs]. Moscow: Novaya Volna. [in Russian].

[2] Antonenko, L. M., \& Parfenov, V. A. (2017). Lekarstvennaya terapiya perifericheskogo vestibulyarnogo golovokruzheniya [Drug therapy for peripheral vestibular vertigo]. Nevrologiya, nejropsikhiatriya, psikhosomatika, 9(1), 106-110. [in Russian].

[3] Ganjali, M., Aghili, S., Larijani, B., \& Ghasemi, M. (2015). Potentiometric Determination of Betahistine in Pharmaceutical Formulations by Drug Selective Sensors. Intternational Journal of Electrochemical Science, 10, 1893-1903.

[4] Gangrade, D., \& Bakshi, S. (2014). RP-HPLC Method Development and Validation for Betahistine Hydrochloride Controlled Release Tablets. Intternational Journal of Chemical and Pharmaceutical Analysis, 2(1), 18-22.

[5] Kalavadiya, B., Joshi, M., Makavana, K., Barochiya, K., \& Kashyap, R. (2013). Development of New Method and Validation for Determination of Betahistin Dihydrochloride in Bulk and Marketed Formulation. Intternational Journal of Pharmaceutical and Chemical Sciences, 2(1), 325-334

[6] Gangrade, D., \& Bakshi, S. (2015). Dissolution Method Development Followed by Spectrophotometric Analysis and Validation of Betahistine Hydrochloride Controlled Release Tablets. Intternational Journal of Chemical and Pharmaceutical Analysis, 2(3), 168-173.

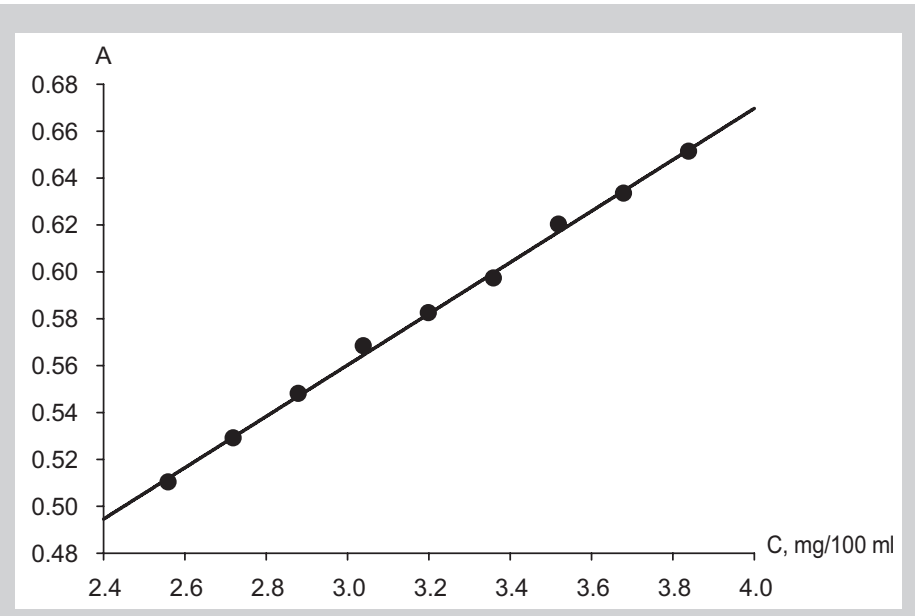

Fig. 4. The calibration graph of the absorption against the concentration of betahistine dihydrochloride.

Table 1. Linear dependence data

\begin{tabular}{llll}
\hline Value & Meaning & Criteria & Conclusion \\
\hline$b \pm\left(s_{b}\right)$ & $0.1095 \pm(0.0018)$ & - & - \\
$a \pm\left(s_{\mathrm{a}}\right)$ & $0.2318 \pm(0.0059)$ & $\mid \mathrm{lal} \leq \frac{0.32 \times \Delta \mathrm{As}(\%)}{1-(\mathrm{Xmin} / 100)}=0.6568$ & conform \\
& & $\leq \Delta_{\mathrm{As}}(\%) / t(95 \% ; 7)=1.055$ & \\
$s_{\mathrm{x}, 0}(\%)$ & 0.0210 & $\geq 0.9970$ & conform \\
$r$ & 0.9990 & & conform \\
\hline
\end{tabular}

Table 2. Determination of the results of coincidence of the betahistine dihydrochloride quantitative determination in tablets $(n=9, P=0.95)$

\begin{tabular}{lllllll}
\hline \multirow{2}{*}{ Dosage form } & \multirow{2}{*}{ Content } & \multicolumn{6}{l}{ Metrological characteristics } \\
\cline { 3 - 7 } & & $\bar{X}$ & $S$ & $R S D$ & $\Delta_{x, r}$ & $\Delta_{A s} \%$ \\
\hline "Vestinorm" & $0.024 \mathrm{~g}$ & 0.0242 & $3.5 \cdot 10^{-4}$ & 1.46 & 2.71 & 3.20 \\
"Maxhistin" & $0.016 \mathrm{~g}$ & 0.0161 & $2.7 \cdot 10^{-4}$ & 1.67 & 3.12 & 3.20 \\
"Betahis" & $0.016 \mathrm{~g}$ & 0.0160 & $2.2 \cdot 10^{-4}$ & 1.41 & 2.62 & 3.20 \\
\hline
\end{tabular}

Table 3. Results of determination of accuracy of betahistine dihydrochloride quantitative determination in tablets by means of standard addition method

\begin{tabular}{lllll}
\hline Dosage form & $\Delta \mathbf{Z}$ & $\boldsymbol{R S D}$ & $\Delta \overline{\mathbf{Z}}$ & $|\overline{\mathbf{Z}}-100|$ \\
\hline "Vestinorm" & 100.51 & 0.65 & 3.66 & 0.51 \\
"Maxhistin" & 100.52 & 0.42 & 2.32 & 0.52 \\
"Betahis" & 101.66 & 1.58 & 8.81 & 1.66 \\
\hline
\end{tabular}

[7] Gangrade, D., \& Bakshi, S. (2014). Spectroscopic method development and validation of betahistine hydrochloride controlled release tablets. Intternational Journal of Innovative Pharmaceutical Sciences and Research, 2(10), 2369-2375.

[8] (2015). Derzhavna Farmakopeia Ukrainy [Ukrainian Pharmacopoeia] Kharkiv: Naukovo-ekspertniy farmakopeyniy tsentr. [in Ukrainian]

[9] Grisodub, A. I. (2016). Standartizirovannye procedury dlya proverk procedur kontrolya kachestva lekarstv [Standardized procedures for the validation of drug quality control methods]. Kharkiv. [in Russian].

\section{Information about authors:}

Donchenko A. O., Aspirant, Department of Analytical Chemistry,

Zaporizhzhia State Medical University, Ukraine.

Vasyuk S. O., Dr. hab., Professor, Head of the Department

of Analytical Chemistry, Zaporizhzhia State Medical University,

Ukraine. 


\section{Відомості про авторів:}

Аонченко А. О., очний аспірант каф. аналітичної хімії,

Запорізький Аержавний меАичний університет, Україна.

Васюк С. 0., А-р фарм. наук, професор, зав. каф. аналітичної

хімії, Запорізький державний медичний університет, Україна.

\section{Сведения об авторах:}

Аонченко А. А., очный аспирант каф. аналитической химии,

Запорожский госуАарственный меАицинский университет,

Украина.

Васюк С. А., А-р фарм. наук, профессор,

зав. каф. аналитической химии, Запорожский государственный медицинский университет, Украина.

Conflicts of Interest: authors have no conflict of interest to declare. Конфмікт інтересів: віАсутній.

Надійшла до редакції / Received: 17.10.2017

Після Аоопрацювання / Revised: 20.11.2017

Прийнято АО Аруку / Accepted: 24.11.2017 